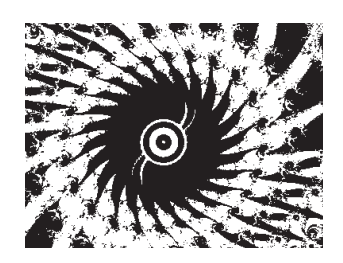

\title{
MOTIVACIJA ZA RODITELJSTVO I BRIGA ZA MLAĐE NARAŠTAJE U MLAĐIH I SREDOVJEČNIH RODITELJA
}

Ivana TUCAK JUNAKOVIĆ, Iva AHMETI

Sveučilište u Zadru, Zadar

UDK: 159.947.5-055.52(497.5)

Izvorni znanstveni rad

Primlieno: 25. 3. 2011.

Provedeno je istraživanje kojemu je prvi cilj bio ispitati odnos četiriju kategorija motivacije za roditeljstvo, prema Rabinu (Rabin, 1965.), i generativne brige ili brige za dobrobit mlađih naraštaja. Roditeljstvo je najuobičajeniji, premda ne i jedini, način izražavanja generativnosti, za koju je stoga pretpostavljeno da bi mogla biti jedan od izvora motivacije za roditeljstvo. Drugi je cili bio ispitati spolne i dobne razlike $u$ motivaciji za roditeljstvo. U istraživanju je sudjelovalo 225 roditelja od 20 do 60 godina. Oni su na Skali motivacije za roditeljstvo procjenjivali razloge zbog kojih su se odlučili imati dijete/djecu, dok je generativna briga ispitana adaptiranom Loyola skalom generativnosti. Rezultati su pokazali da je generativna briga značajno, ali nisko, povezana s altruističnom i s instrumentalnom motivacijom za roditelistvo, dok s fatalištičnom i narcističnom motivacijom nije značajno korelirala. Žene su imale izraženiju altruističnu motivaciju nego muškarci, dok su muškarci imali izraženiju instrumentalnu motivaciju nego žene. Uz kontrolu broja diece, roditelii mlađe i srednje odrasle dobi nisu se značajno razlikovali u procjenama pojedinih kategorija motivacije za roditeljstvo. Međutim, dob je u interakciji sa spolom ispitanika imala značajan učinak na altruističnu i instrumentalnu motivaciju.

Ključne riječi: motivacija za roditeljstvo, generativna briga, spolne i dobne razlike

Ivana Tucak Junaković, Sveučilište u Zadru, Odjel za psihologiju, Obala kralja Petra Krešimira IV. br. 2, 23000 Zadar, Hrvatska.

E-mail: itucak@unizd.hr 
"Zašto ljudi žele imati djecu?" pitanje je na koje su mnogi teoretičari pokušali odgovoriti. Motivaciju za roditeljstvo nije lako istraživati, jer se pokazalo da ljudi teško opisuju razloge zbog kojih žele imati djecu, vjerojatno zato što je riječ o vrlo intimnom području života ili zato što te razloge nisu ni osvijestili. Uz to, djeca su u većini društava poželjan i vrijedan cilj (Čudina-Obradović i Obradović, 2006.), pa ljudi daju socijalno poželjne odgovore o razlozima zbog kojih su se odlučili imati djecu.

Hoffman i Hoffman (1973.) među prvima su temeljitije ispitali vrijednost koju djeca imaju za roditelje. Utvrdili su devet skupina takvih vrijednosti, od onih ekonomskih i praktičnih (npr. dokazivanje statusa odrasle osobe ili ekonomski dobitak) do psiholoških (npr. radost roditeljstva). Čini se da s napretkom društva opada ekonomska vrijednost djeteta (npr. dijete kao radna snaga ili oslonac u starosti), a povećava se njegova psihološka vrijednost (uzajamna ljubav, privrženost, osjećaj ispunjenosti i dr.) (prema Cudina-Obradović i Obradović, 2006.).

Istraživanja su pokazala da na fertilitetnu motivaciju utječu brojni činitelji, od bioloških, osobnih značajki potencijalnih roditelja (psihološke potrebe, stavovi i vrijednosti), socioekonomskih činitelja (materijalno stanje, obrazovanje, zaposlenje, stambeno pitanje), kvalitete partnerskog odnosa potencijalnih roditelja do povijesno-društvenih okolnosti i unutarnjih normi vezanih uz fertilitetno ponašanje koje je pojedinac usvojio tijekom socijalizacije u obitelji djetinjstva i široj društvenoj sredini (Adler, 1997.; Friedman i sur., 1994.; Kohler i sur., 1999.; Schoen i sur., 1997.). Također, motivi za roditeljstvo kod onih koji već jesu roditelji mogu se mijenjati ovisno o spolu, broju djece i njihovu redoslijedu rođenja (Miller i Pasta, 1994.; Teachman i Schollaert, 1989.).

Jedan od prvih odgovora na pitanje što roditelji očekuju od djece i kakve im potrebe djeca trebaju zadovoljiti dao je Rabin (1965.), koji je motivaciju za roditeljstvo grupirao u četiri kategorije. Altruistična motivacija uključuje ljubav prema djeci, želju da se o njima brine, da im se pruži ljubav i zaštita i sl. Fatalistična se odnosi na uvjerenje da je reprodukcija i produženje vrste smisao života, ljudska sudbina ili Božja volja; to je nešto što je predodređeno i neizbježno. Kada se dijete rabi kao sredstvo kojim se mogu postići neki specifični roditeljski ciljevi (npr. materijalna dobit, ispomoć u starosti i dr.), radi se o instrumentalnoj motivaciji. I na kraju, narcistična motivacija za roditeljstvo odnosi se na očekivanje da će dijete povećati vrijednost roditelja, da će ono biti dokaz njegove seksualne sposobnosti te maskulinosti, odnosno femininosti. Primjenom 
DRUŠ. ISTRAŽ. ZAGREB GOD. 21 (2012), BR. 2 (116)

STR. 363-382

TUCAK JUNAKOVIĆ, I., AHMETI, I.:

MOTIVACIJA ZA... upitnika koji je konstruirao u svrhu ispitivanja motivacije za roditeljstvo na studentima jednoga američkog sveučilišta Rabin je (1965.) utvrdio da oko 50\% ispitanika navodi da su osnovni motivi za roditeljstvo u muškaraca motivi narcistične prirode (npr. povećanje ugleda, dokaz maskulinosti i plodnosti), a u žena fatalistični motivi (instinkt materinstva, sudbina). S druge strane, Kapor-Stanulović je (1984.) u istraživanju na adolescentima, studentima i odraslima utvrdila da su altruistični motivi izraženiji u djevojaka nego u mladića, ali da se te spolne razlike gube $u$ bračnih parova s djecom. $\mathrm{Na}$ svim ispitanim uzrastima muškarci su pokazali jaču fatalističnu motivaciju, dok u instrumentalnoj i narcističnoj nije bilo značajnih spolnih razlika. Nadalje, autorica je utvrdila da se altruistični motivi nakon adolescencije pojačavaju, narcistični s dobi i iskustvom opadaju, dok se jačina fatalističnih motiva s dobi značajno ne mijenja.

U istraživanju na uzorcima hrvatskih ispitanika, bračnih parova i studenata potvrđene su sve četiri Rabinove kategorije motivacije za roditeljstvo (Lacković-Grgin i Vitez, 1997.). Pritom su tri pokazale jednofaktorsku strukturu, dok je instrumentalna motivacija uključivala četiri faktora. To su: potvrđivanje sebe, produženje obiteljske loze, očuvanje stabilnosti braka i domoljubna motivacija. Autorice su u istraživanju rabile skalu koju su same konstruirale na temelju odgovora dobivenih $\mathrm{u}$ intervjuima s bračnim parovima i studentima o tome zašto žele imati djecu, odnosno zašto nemaju djecu (Skala motivacije za roditeljstvo, Lacković-Grgin i Vitez, 1997., 2002.).

Iako je nedvojbeno da je motivacija za roditeljstvo višestruko determinirana, kao širi teorijski okvir u proučavanju ove motivacije, kako navode Lacković-Grgin i Vitez (1997.), mogao bi se uzeti koncept generativnosti. Ovaj je koncept razradio Erikson unutar svoje psihosocijalne teorije razvoja. Definirao ga je kao "brigu za stvaranje i vođenje sljedećeg naraštaja" (Erikson, 1984., 240) i glavno obilježje sedmoga stadija razvoja ili srednje odrasle dobi. Nakon Eriksona konstrukt generativnosti doživio je brojne interpretacije (Bradley, 1997.; Kotre, 1984.; McAdams i de St. Aubin, 1992.; Peterson i Klohnen, 1995.; Stewart i Vandewater, 1998. itd.), pa se generativnost danas može opisati kao širok pojam koji uključuje stvaranje i brigu o djeci, materijalnim proizvodima i idejama koji će nadživjeti pojedinca i koji pridonose dobrobiti i kontinuitetu društva. Logično je pretpostaviti da bi ova opća briga mogla biti jedan od izvora motivacije za roditeljstvo. I sam Erikson navodi da je roditeljstvo najuobičajeniji, premda ne i jedini, način izražavanja generativnosti.

Međutim, kako je generativnost širok koncept koji uključuje različite aspekte, valja pretpostaviti da neće biti u istom od- 
DRUŠ. ISTRAŽ. ZAGREB GOD. 21 (2012)

BR. $2(116)$

STR. 363-382

TUCAK JUNAKOVIĆ, I., AHMETI, I.:

MOTIVACIJA ZA... nosu sa svim vrstama motivacije za roditeljstvo koje se međusobno dosta razlikuju. Točnije, moglo bi se pretpostaviti da je generativnost uže povezana s altruističnom i s instrumentalnom motivacijom (posebno s njezinom dimenzijom koja se odnosi na produženje obiteljske loze i ostavljanje traga za sobom putem djece), nego s fatalističnom i narcističnom. Naime, altruistična motivacija odnosi se na nesebičnu želju za roditeljstvom koja proizlazi iz ljubavi prema djeci, želje da se o njima brine, da ih se zaštiti i sl. S druge strane, kod generativnosti je naglašeno vođenje, pomaganje i briga za pripadnike mlađih naraštaja. Ovaj aspekt generativnosti odražava tendenciju zajedništva (communion), koja se odnosi na želju da se brine, njeguje, pomaže i podučava druge, posebno pripadnike mlađih naraštaja (Stewart i sur., 1988.). Stoga bi se i moglo pretpostaviti da će osobe koje pokazuju izraženiju brigu za pripadnike mlađih naraštaja imati i izraženiju altruističnu nesebičnu motivaciju za roditeljstvo. $S$ druge strane, $u$ osnovi pretpostavljene povezanosti instrumentalnih motiva za roditeljstvo koji se odnose na nastavljanje obiteljske loze i ostavljanje traga za sobom putem vlastitih potomaka s generativnom brigom trebao bi biti onaj aspekt generativnosti koji su brojni teoretičari generativnosti (Helgeson, 1994.; Kotre, 1984.; McAdams, 1993.; McAdams i sur., 1996. i dr.) nazvali djelovanje (agency). Ovaj aspekt generativnosti odnosi se na želju da se ostavi značajan trag za sobom po kojem će se pojedinca pamtiti i nakon njegove smrti. Ta se želja, među ostalim, može ostvariti i vlastitom djecom koja će nastaviti obiteljsku lozu i koja su produžetak vlastita bića.

U dosadašnjim istraživanjima odnosa generativnosti i činitelja koji su na neki način vezani uz roditeljstvo ispitivan je odnos generativnosti sa samim roditeljskim statusom (McAdams i de St. Aubin, 1992.; Peterson i Klohnen, 1995.; Peterson i Stewart, 1993.; Snarey i Clark, 1998.), s roditeljskim aktivnostima, odgojnim metodama i stilovima roditeljstva (Peterson i sur., 1997.; Pratt i sur., 2001.) te s osobnim značajkama djece (Peterson, 2006.). Međutim, odnos motivacije za roditeljstvo i generativnosti, koja bi mogla biti jedan od pokretača ove motivacije, koliko znamo, dosad nije ispitivan.

Stoga je prvi cilj ovoga istraživanja bio ispitati odnos generativnosti s raznim vrstama motivacije za roditeljstvo u uzorku roditelja mlađe i srednje odrasle dobi. Pritom se pošlo od Rabinove podjele motiva za roditeljstvo, dok je koncept generativnosti predstavljen generativnom brigom (generative concern). Generativna briga, definirana kao opća svjesna usmjerenost na dobrobit sljedeće generacije, ključna je komponenta McAdamsova i de St. Aubinova modela generativnosti (McAdams i de St. Aubin, 1992.), a u istraživanjima je obično pois- 
DRUŠ. ISTRAŽ. ZAGREB GOD. 21 (2012), BR. 2 (116)

STR. 363-382

TUCAK JUNAKOVIĆ, I., AHMETI, I.: MOTIVACIJA ZA.. tovjećivana sa samim konceptom generativnosti. Kao što je već objašnjeno, pretpostavljeno je da će generativna briga biti $\mathrm{u}$ najužoj vezi $\mathrm{s}$ altruističnom $\mathrm{i}$ instrumentalnom motivacijom za roditeljstvo.

Važno je spomenuti da, za razliku od Eriksona, McAdams i de St. Aubin (1992.), tvorci najpoznatijega i najobuhvatnijega modela generativnosti, smatraju da generativnost nije isključivo obilježje srednje dobi. Oni navode da se generativnost razvija postupno u cijeloj odrasloj dobi, odnosno da se javlja i u ranoj odrasloj dobi u kojoj je postati roditeljem jedan od najvažnijih razvojnih zadataka.

Drugi je cilj ovoga istraživanja bio utvrditi postoje li spolne i dobne razlike u motivaciji za roditeljstvo. $\mathrm{S}$ obzirom na razlike $\mathrm{u}$ socijalizaciji rodnih uloga i rezultate nekih ranijih istraživanja (Kapor-Stanulović, 1984.; Lacković-Grgin i Vitez, 1997.), pretpostavljeno je da će žene imati izraženiju altruističnu motivaciju nego muškarci. S obzirom na nesuglasne pretpostavke i rezultate ranijih istraživanja spolnih razlika u ostalim trima kategorijama motiva za roditeljstvo (Kapor-Stanulović, 1984., 1985.; Lacković-Grgin i Vitez, 1997.; Rabin, 1965.), za fatalistične, narcistične i instrumentalne motive nisu formirane eksplicitne pretpostavke o značajnosti i smjeru eventualnih spolnih razlika. Nadalje, pretpostavljeno je da se, bez obzira na s dobi očekivanu sve veću spremnost odraslih da prihvate roditeljsku ulogu i da se brinu o mlađim naraštajima, roditelji mlađe i srednje odrasle dobi neće značajno razlikovati u pojedinim kategorijama fertilitetne motivacije. To je stoga što je riječ o retrogradnoj procjeni fertilitetne motivacije. Ispitanici nisu procjenjivali razloge zbog kojih bi željeli imati djecu u budućnosti, a koji bi mogli biti pod utjecajem njihove dobi, već razloge zbog kojih su se odlučili imati dijete/djecu koju već imaju. I ispitanici mlađe i oni srednje dobi, bez obzira na njihovu trenutačnu dob i na vrijeme koje je za njih proteklo između donošenja fertilitetne odluke i trenutka ispitivanja fertilitetne motivacije, odluku da postanu roditeljima donijeli su i roditeljima postali uglavnom $\mathrm{u}$ istom razdoblju, tj. u mlađoj odrasloj dobi.

\section{METODA}

\section{Sudionici i postupak ispitivanja}

U istraživanju je sudjelovalo 225 osoba od 20 do 60 godina $(\mathrm{M}=40,3, \mathrm{SD}=12,35)$, od čega 110 muškaraca i 115 žena. Sudionike su za istraživanje regrutirali studenti Odjela za psihologiju Sveučilišta u Zadru individualnim kontaktima. Sudionici su regrutirani iz urbanih i ruralnih sredina iz raznih dijelova Hrvatske, ali najvećim dijelom (75\% uzorka) iz Dal- 
DRUŠ. ISTRAŽ. ZAGREB GOD. 21 (2012) BR. $2(116)$

STR. 363-382

TUCAK JUNAKOVIĆ, I., AHMETI, I.

MOTIVACIJA ZA...

\section{Instrumenti}

macije. Pošto bi nakon upoznavanja sa svrhom istraživanja pristali na sudjelovanje, sudionici bi dobili materijale s osnovnim podacima o istraživanju, molbom za suradnju i upitnikom koji su ispunjavali u svoje slobodno vrijeme, tj. bez prisutnosti studenata ispitivača. Ispitivači bi potom preuzimali zatvorene omotnice $\mathrm{s}$ ispunjenim upitnicima $\mathrm{u}$ domovima ili na radnim mjestima ispitanika.

Uzorak je prigodan, premda se prilikom kontaktiranja potencijalnih sudionika nastojalo da različite dobne podskupine uzorka budu otprilike ravnomjerno zastupljene. S obzirom na istraživačke probleme, odnosno pretpostavku da su roditeljstvo i generativnost zadaci koji primarno zaokupljaju osobe mlađe i srednje odrasle dobi, jedini uvjet za sudjelovanje $u$ istraživanju (uz, naravno, dobrovoljnost) bio je da ispitanici budu osobe mlađe ili srednje odrasle dobi koje imaju barem jedno dijete. Većina sudionika istraživanja živjela je u bračnoj zajednici (93\%), dok je preostalih 7\% živjelo u izvanbračnoj vezi. Pritom treba napomenuti da $u$ istraživanju nisu sudjelovali parovi, tj. oba partnera iz bračne ili izvanbračne zajednice. Svi ispitanici bili su roditelji koji su imali od jednoga djeteta do petero djece. Većina je imala dvoje djece $(\mathrm{M}=2,2, \mathrm{SD}=0,74 \mathrm{Mod}=2)$. Nadalje, većina sudionika imala je srednju stručnu spremu (71\%), a ostali višu (8\%) ili visoku $(21 \%)$. Većina je bila zaposlena (85\%), a ostali sudionici bili su nezaposleni (4\%) ili umirovljeni (11\%). Zbog kasnije analize spolnih razlika u motivaciji za roditeljstvo treba naglasiti da se muškarci i žene ovoga uzorka nisu značajno razlikovali $(p>0,05)$ s obzirom na relevantne varijable: dob $(t=0,12)$, stručnu spremu $\left(\chi^{2}=0,69\right)$, radni status $\left(\chi^{2}=0,83\right)$, bračno stanje $\left(\chi^{2}=0,23\right)$ i broj djece $(t=0,15)$.

U istraživanju je primijenjen upitnik koji je uključivao pitanja o nekim sociodemografskim obilježjima (spol, dob, godine školovanja/stručna sprema, radni status, bračno stanje i broj djece), Skalu motivacije za roditeljstvo i adaptiranu Loyola skalu generativnosti.

Skala motivacije za roditeljstvo (MZR, Lacković-Grgin i Vitez, 2002.) sastoji se od 52 čestice koje ispituju četiri Rabinove kategorije motivacije za roditeljstvo. Svaka čestica odražava mogući razlog zbog kojeg se osoba odlučila imati dijete/djecu. Podskala altruistične motivacije sadrži 12 čestica (npr. "zato što djeca uljepšavaju život", "zato što volim djecu"). Podskala fatalistične motivacije također uključuje 12 čestica (npr. "čovjek je stvoren da ima djecu", "to je božja volja"). Podskala narcistične motivacije sadrži samo 5 čestica (npr. "radi dokazivanja sebe, da sam sposoban imati djecu", "djeca su dokaz 
DRUŠ. ISTRAŽ. ZAGREB GOD. 21 (2012), BR. 2 (116)

STR. 363-382

TUCAK JUNAKOVIĆ, I., AHMETI, I.: MOTIVACIJA ZA... moje muškosti/ženstvenosti"), dok ih podskala instrumentalne motivacije sadrži čak 23 (npr. "zato što djeca učvršćuju brak", "radi pokoljenja/nastavljanja loze"). Ispitanici na skali od pet stupnjeva (od 0 - uopće se ne slažem do 4 - potpuno se slažem) procjenjuju koliko se slažu sa svakom tvrdnjom na skali, tj. s određenim motivom za roditeljstvo kao vlastitim. Ukupan rezultat izračunava se za svaku od četiri podskale kao zbroj procjena na pripadajućim česticama. Kao što je već rečeno, $\mathrm{u}$ ovom su istraživanju ispitanici procjenjivali razloge zbog kojih su se odlučili imati dijete/djecu koju već imaju, a ne razloge zbog kojih bi željeli imati djecu u budućnosti.

Eksploratornom analizom na zajedničke faktore rezultata dobivenih na MZR skali $u$ ovom istraživanju izdvojeno je osam faktora, koje je bilo teško interpretirati. Pritom su mnoge čestice bile značajno zasićene većim brojem faktora. Stoga je u nastavku provedena analiza sa četiri zadana faktora kako bi se provjerila pretpostavka autorica skale da skala mjeri Rabinove četiri kategorije fertilitetne motivacije. Ova su četiri faktora, s obzirom na čestice njima zasićene, potvrdila pretpostavke autorica skale, tj. riječ je o faktorima altruistične, fatalistične, narcistične i instrumentalne motivacije. Nadalje je analizom na zajedničke faktore provjerena faktorska struktura svake od četiri podskale. Pokazalo se da su sve podskale jednofaktorske, osim podskale instrumentalne motivacije, koja je pokazala trofaktorsku, za razliku od četverofaktorske strukture iste podskale dobivene $\mathrm{u}$ ranijem istraživanju Lacković-Grgin i Vitez (1997.). Prvi se faktor podskale instrumentalne motivacije odnosio na očuvanje stabilnosti braka i sigurnost $\mathrm{u}$ starosti kao motive za roditeljstvo. Drugi je faktor bio nešto heterogenijega sadržaja, a najveće zasićenje njime imale su čestice koje se odnose na postizanje većega društvenog statusa i domoljubne motive za roditeljstvo. Treći se faktor odnosio na produženje obiteljske loze i ostavljanje traga za sobom uz pomoć djece. S obzirom na utvrđenu trofaktorsku strukturu, osim ukupnog rezultata na skali instrumentalne motivacije, izračunavani su i ukupni rezultati za svaku od njezine tri podskale.

Kako je ovo tek druga provjera psihometrijskih svojstava MZR skale, $u$ nastavku su provedene i konfirmatorne faktorske analize svake od četiriju glavnih skala fertilitetne motivacije i svake od triju podskala instrumentalne motivacije. U svakoj je analizi pojedina vrsta fertilitetne motivacije predstavljala latentnu varijablu, a čestice pripadajuće skale njezine indikatore. Procjene parametara provedene su uz pomoć algoritma maksimalne vjerojatnosti. U nastavku su prikazani dobiveni pokazatelji slaganja modela s podacima. Za skalu al- 
DRUŠ. ISTRAŽ. ZAGREB GOD. 21 (2012) BR. $2(116)$

STR. 363-382

TUCAK JUNAKOVIĆ, I., AHMETI, I.:

MOTIVACIJA ZA... truistične motivacije iznosili su: $\chi^{2} / \mathrm{df}=2,73, \mathrm{CFI}=0,86, \mathrm{TLI}=0,82$, RMSEA $=0,09(0,077-0,124)$, SRMR $=0,06$. Za skalu fatalistične motivacije iznosili su: $\chi^{2} / \mathrm{df}=1,69, \mathrm{CFI}=0,95$, TLI $=0,94$, RMSEA $=0,07$ $(0,044-0,095), \mathrm{SRMR}=0,05$. Za skalu narcistične motivacije iznosili su: $\chi^{2} / \mathrm{df}=3,16, \mathrm{CFI}=0,91$, TLI $=0,80$, RMSEA $=0,12(0,093-0,185)$, $\mathrm{SRMR}=0,05$. Za skalu instrumentalne motivacije u cjelini s jednom latentnom varijablom dobiveni su pokazatelji nižeg slaganja: $\chi^{2} / \mathrm{df}=3,39, \mathrm{CFI}=0,75$, TLI=0,70, RMSEA $=0,13(0,124-0,146)$, $\mathrm{SRMR}=0,08$. Za prvu podskalu instrumentalne motivacije dobiveni su sljedeći pokazatelji slaganja: $\chi^{2} / \mathrm{df}=2,44, \mathrm{CFI}=0,97$, TLI $=0,94$, RMSEA $=0,10(0,044-0,158)$, SRMR $=0,03$, za drugu podskalu: $\chi^{2} / \mathrm{df}=3,34, \mathrm{CFI}=0,84, \mathrm{TLI}=0,77, \mathrm{RMSEA}=0,13$ $(0,109-0,156)$, SRMR $=0,06$, a za treću podskalu instrumentalne motivacije: $\chi^{2} / \mathrm{df}=2,85, \mathrm{CFI}=0,96, \mathrm{TLI}=0,93, \mathrm{RMSEA}=0,11$ $(0,061-0,171)$, SRMR $=0,04$. Dobiveni pokazatelji slaganja, ovisno o tome o kojem se pokazatelju i o kojoj skali radi, upućuju na djelomično do dobro slaganje modela s podacima. Ono je najlošije za skalu instrumentalne motivacije u cjelini, kada je specificirana kao jednofaktorska, te za drugu podskalu instrumentalne motivacije, jer su obje dosta heterogena sadržaja.

Rezultati konfirmatorne analize nadalje su pokazali da su faktorska zasićenja pojedinih indikatora (čestica) pripadajućim latentnim konstruktom (određenom vrstom fertilitetne motivacije) bez iznimke statistički značajna ( $p<0,01)$, a njihove standardizirane vrijednosti znatno veće od prihvatliivih 0,30 .

Koeficijenti Cronbach-alpha za pojedine podskale, prikazani u Tablici 1, pokazuju njihovu zadovoljavajuću pouzdanost.

Adaptirana Loyola skala generationosti (LGS, McAdams i de St. Aubin, 1992.; Lacković-Grgin i sur., 2002.) ispituje generativnu brigu ili opću usmjerenost na dobrobit mlađih generacija, glavnu komponentu McAdamsova i de St. Aubinova modela generativnosti. Adaptirana verzija LGS, prilagođena ispitivanju ovoga konstrukta u hrvatskom kulturalnom okruženju, za razliku od originalne skale od 20, sadrži 17 čestica (npr. "Osjećam da će moji doprinosi postojati i nakon moje smrti", "Nastojim prenijeti znanje koje sam stekao vlastitim iskustvom" itd.). Ispitanici na ovoj adaptiranoj verziji skale procjenjuju na Likertovoj skali od 5 stupnjeva (od 1 do 5) koliko se svaka čestica na njih odnosi. Ukupan rezultat se formira zbrajanjem procjena na pojedinim česticama skale. Pritom viši rezultat upućuje na izraženiju generativnu brigu.

Skala je u ovoj, kao i u brojnim ranijim, primjenama (npr. Lacković-Grgin i sur., 2002.; Tucak, 2005.) pokazala zadovoljavajuća psihometrijska svojstva. I u ovom je istraživanju potvrđena njezina jednofaktorska struktura, a Cronbach-alpha iznosio je 0,87 . 
Osnovni deskriptivni statistici skala koje su upotrijebljene $\mathrm{u}$ ovom istraživanju prikazani su u Tablici 1.

\begin{tabular}{|c|c|c|c|c|c|}
\hline Skala & $\mathrm{M}$ & SD & Raspon & $\begin{array}{r}\text { Broj } \\
\text { čestica }\end{array}$ & $\alpha$ \\
\hline Loyola skala generativnosti & $60,24(3,54)^{4}$ & 9,45 & $33,00-85,00$ & 17 & 0,87 \\
\hline Podskala altruistične motivacije & $41,46(3,45)$ & 6,30 & $16,00-48,00$ & 12 & 0,87 \\
\hline Podskala fatalistične motivacije & $29,48(2,46)$ & 10,21 & $2,00-48,00$ & 12 & 0,88 \\
\hline Podskala narcistične motivacije & $8,72(1,74)$ & 4,16 & $0,00-20,00$ & 5 & 0,75 \\
\hline Podskala instrumentalne motivacije & $43,99(1,91)$ & 17,64 & $0,00-85,00$ & 23 & 0,92 \\
\hline Podskala instrumentalne motivacije ${ }^{1}$ & $13,88(2,31)$ & 5,90 & $0,00-24,00$ & 6 & 0,88 \\
\hline Podskala instrumentalne motivacije 2 & $12,84(1,43)$ & 7,46 & $0,00-32,00$ & 9 & 0,86 \\
\hline Podskala instrumentalne motivacije ${ }^{3}$ & $17,55(2,19)$ & 7,09 & $0,00-32,00$ & 8 & 0,87 \\
\hline
\end{tabular}

1 dio podskale instrumentalne motivacije koji se odnosi na očuvanje stabilnosti braka i sigurnost u starosti

2 dio podskale instrumentalne motivacije koji se odnosi na postizanje većega statusa u društvu i domoljubne motive za roditeljstvo

3 dio podskale instrumentalne motivacije koji se odnosi na produženje obiteljske loze i ostavljanje traga za sobom uz pomoć djece

4 u zagradama su navedene prosječne vrijednosti rezultata na pojedinim skalama dobivene dijeljenjem zbroja procjena na pojedinim česticama skale brojem čestica

( TABLICA 1

Osnovni deskriptivni podaci za adaptiranu Loyola skalu generativnosti i podskale motivacije za roditeljstvo $(\mathrm{N}=225)$
Deskriptivni statistici skala prikazani u Tablici 1 upućuju na njihovu zadovoljavajuću osjetljivost i pouzdanost. Uvid u prosječne vrijednosti rezultata, prikazane $u$ zagradama, pokazuje da su rezultati na adaptiranoj Loyola skali generativnosti donekle pomaknuti prema višim vrijednostima. Naime, kada se ukupan rezultat na skali izračuna kao prosječna vrijednost procjena na pojedinim česticama, onda se teoretski raspon rezultata na ovoj skali kreće od 1 do 5 , a na podskalama motivacije za roditeljstvo od 0 do 4 . $U$ pogledu jačine zastupljenosti pojedinih kategorija motiva za roditeljstvo, pokazalo se da su najzastupljeniji altruistični, zatim fatalistični i instrumentalni, dok su najmanje zastupljeni narcistični motivi. Među instrumentalnim motivima najzastupljeniji su oni koji se odnose na očuvanje stabilnosti braka i sigurnost $u$ starosti, a nakon njih na produženje obiteljske loze i ostavljanje traga za sobom uz pomoć djece. Najmanje zastupljeni instrumentalni motivi jesu oni koji se odnose na postizanje višega društvenog statusa i domoljubne motive za roditeljstvo.

Rezultati korelacijskih analiza, prikazani u Tablici 2, pokazali su da četiri osnovne kategorije motiva za roditeljstvo pozitivno i uglavnom umjereno visoko koreliraju. Pritom su najuže povezane instrumentalna motivacija s narcističnom i fatalističnom motivacijom te narcistična i fatalistična motivacija. Čak je i altruistična motivacija bila umjereno visoko po- 
DRUŠ. ISTRAŽ. ZAGREB GOD. 21 (2012)

BR. $2(116)$

STR. 363-382

TUCAK JUNAKOVIĆ, I., AHMETI, I.:

MOTIVACIJA ZA...

vezana s fatalističnom i instrumentalnom te nisko, ali i dalje značajno pozitivno povezana is narcističnom motivacijom za roditeljstvo. Kao što se moglo i očekivati, tri su skupine instrumentalnih motiva značajno međusobno korelirale. Također su značajno i uglavnom umjereno visoko korelirale i sa svim ostalim kategorijama motivacije za roditeljstvo. Jedino instrumentalni motivi koji se odnose na postizanje većega društvenog statusa i na domoljubne motive nisu značajno korelirali s altruističnim motivima za roditeljstvo.

\begin{tabular}{|c|c|c|c|c|c|c|c|c|c|}
\hline Varijabla & 1. & 2. & 3. & 4. & 5. & 6. & 7. & 8. & 9. \\
\hline 1. Generativna briga & 1,00 & & & & & & & & \\
\hline 2. Altruistična motivacija & $0,19^{* *}\left(0,16^{*}\right)$ & 1,00 & & & & & & & \\
\hline 3. Fatalistična motivacija & $0,09 \quad(0,08)$ & $0,41^{* *}$ & 1,00 & & & & & & \\
\hline 4. Narcistična motivacija & $0,10 \quad(0,14)$ & $0,16^{*}$ & $0,59^{* *}$ & * 1,00 & & & & & \\
\hline 5. Instrumentalna motivacija & $0,17^{*}\left(0,16^{*}\right)$ & $0,30^{* *}$ & $0,62^{* *}$ & * $0,73^{* *}$ & 1,00 & & & & \\
\hline 6. Instrumentalna motivacija ${ }^{1}$ & $0,15^{*} \quad(0,11)$ & $0,31^{* *}$ & $0,53^{* *}$ & * $0,50^{* *}$ & $0,82^{* *}$ & $+1,00$ & & & \\
\hline 7. Instrumentalna motivacija ${ }^{2}$ & $0,13 \quad(0,14)$ & 0,14 & $0,57^{* *}$ & * $0,78^{* *}$ & $0,85^{* *}$ & * $0,54^{* *}$ & 1,00 & & \\
\hline 8. Instrumentalna motivacija ${ }^{3}$ & $0,14 \quad(0,15)$ & $0,32^{* *}$ & $0,48^{* *}$ & * $0,55^{* *}$ & $0,86^{* *}$ & * $0,60^{* *}$ & $0,58^{* *}$ & * 1,00 & \\
\hline 9. Broj djece & 0,11 & $0,41^{* *}$ & $0,20^{*}$ & $-0,09$ & 0,12 & $0,19^{*}$ & 0,05 & 0,08 & 1,00 \\
\hline
\end{tabular}

${ }^{*} \mathrm{p}<0,05,{ }^{* *} \mathrm{p}<0,01$

Napomene: U zagradama su prikazani koeficijenti parcijalne korelacije generativne brige i pojedinih kategorija motivacije za roditeljstvo, nakon kontrole broja djece. 1,2,3 znače isto što i u Tablici 1.

(1) TABLICA 2 Koeficijenti povezanosti generativne brige, pojedinih kategorija motivacije za roditelistvo i broja diece $(\mathrm{N}=225)$
Prvi istraživački problem bio je ispitati odnos generativne brige i pojedinih Rabinovih kategorija motivacije za roditeljstvo. Koeficijenti korelacija (Tablica 2) pokazali su da je, u skladu s očekivanjima, generativna briga uže povezana $s$ altruističnom i instrumentalnom nego s fatalističnom i narcističnom motivacijom za roditeljstvo. U najužoj je vezi s nesebičnim altruističnim motivima. Za razliku od koeficijenata povezanosti s fatalističnom i narcističnom motivacijom, koeficijenti povezanosti generativne brige s altruističnom i instrumentalnom motivacijom značajni su, ali niski. Međutim, generativna je briga od tri skupine instrumentalnih motiva značajno, premda nisko, korelirala samo s onima koji se odnose na očuvanje stabilnosti braka i sigurnost u starosti, što se navodilo kao razloge zbog kojih su se sudionici ovoga istraživanja odlučili imati dijete/djecu.

Kako je pretpostavljeno da bi retrogradne procjene motivacije za roditeljstvo mogle biti pod utjecajem broja djece koju ispitanici imaju, provjereno je ostaju li ove korelacija generativne brige $s$ altruističnom i s instrumentalnom motivacijom značajne i nakon parcijalizacije utjecaja broja djece. Te su korelacije nakon kontrole broja djece ostale značajne $(p<0,05)$, ali su njihove vrijednosti pale (v. Tablicu 2). Nakon parcijalizacije utjecaja broja djece opao je i koeficijent korelacije iz- 
DRUŠ. ISTRAŽ. ZAGREB GOD. 21 (2012), BR. 2 (116)

STR. 363-382

TUCAK JUNAKOVIĆ, I., AHMETI, I.: MOTIVACIJA ZA... među generativne brige i one vrste instrumentalne motivacije koja se odnosi na očuvanje stabilnosti braka i sigurnost $u$ starosti, pa taj koeficijent više nije bio značajan (v. Tablicu 2). Ovaj pad u koeficijentima povezanosti generativne brige $\mathrm{s}$ altruističnom i instrumentalnom motivacijom (točnije, s njezinom prvom podskalom) sugerira da je broj djece utjecao na povezanost generativne brige i na ovaj način procijenjenih dviju kategorija fertilitetne motivacije.

Provjereni su i koeficijenti povezanosti četiriju vrsta motivacije za roditeljstvo i generativne brige s brojem djece. Prikazani su u Tablici 2. Dobiveni koeficijenti korelacije uistinu su i pokazali da altruistična motivacija umjereno visoko korelira s brojem djece. Uz altruističnu, i fatalistična te ona vrsta instrumentalne motivacije koja se odnosi na očuvanje stabilnosti braka i sigurnost u starosti kao razloge za roditeljstvo također značajno, iako nisko, koreliraju s brojem djece.

Kako i socioekonomski činitelji mogu utjecati na fertilitetnu motivaciju, kao i na generativnost, provjeren je odnos stupnja obrazovanja (kao jednog od indikatora socioekonomskoga položaja) s fertilitetnom motivacijom i generativnom brigom. Pokazalo se da završene godine školovanja ne koreliraju značajno s vrstama motivacije za roditeljstvo kao ni s generativnom brigom te da se osobe završenoga srednjoškolskog obrazovanja $u$ odnosu na one sa završenom višom i visokom školom ne razlikuju značajno s obzirom na različite kategorije fertilitetne motivacije i generativnu brigu. Međutim, treba naglasiti da je uzorak s obzirom na obrazovanje ograničenoga varijabiliteta, jer je velika većina sudionika imala srednju stručnu spremu (71\%), a u uzorku nije bilo onih sa samo osnovnoškolskim, kao ni onih sa završenim poslijediplomskim, obrazovanjem.

Kako bi se postigao drugi istraživački cilj, tj. provjerilo postoje li spolne i dobne razlike u motivaciji za roditeljstvo, provedene su dvosmjerne analize kovarijance sa spolom i dobi (mlađi i sredovječni odrasli) kao nezavisnim varijablama i njihovim interakcijskim utjecajem te pojedinom kategorijom motivacije za roditeljstvo kao zavisnom varijablom. Za potrebe analize dobnih razlika sudionici su podijeljeni u dvije podskupine: mlađe (20-40 godina; $\mathrm{M}=33,05, \mathrm{~N}=114)$ i sredovječne (41-60 godina; $\mathrm{M}=52,13, \mathrm{~N}=111$ ) odrasle. Kako je prethodno utvrđeno da je broj djece (za razliku od stupnja obrazovanja) značajno povezan s nekim vrstama motivacije za roditeljstvo, samo je broj djece u ove analize uvršten kao kovarijata. Glavni efekti obje nezavisne varijable i njihov interakcijski učinak testirani su nakon što je kontroliran učinak broja djece sudionika istraživanja. Premda provjera spolnih i dobnih razlika u generativnoj brizi nije navedena kao problem ovoga istraživanja, moguće spolne i dobne razlike (uz 
kontrolu utjecaja broja djece) provjerene su i za ovu varijablu. Rezultati ANCOVA prikazani su u Tablici 3.

\begin{tabular}{|c|c|c|c|c|}
\hline & $\frac{\text { Kovarijata: }}{\text { broj djece }(\mathrm{df}=1)}$ & $\frac{\mathrm{Gl}}{\operatorname{spol}(\mathrm{df}=1)}$ & $\frac{\text { avni efekti: }}{\mathrm{dob}(\mathrm{df}=1)}$ & $\frac{\text { Interakcija: }}{\operatorname{spol} \times \operatorname{dob}(\mathrm{df}=1)}$ \\
\hline Altruistična motivacija & $19,75^{* * *}$ & $8,00^{* *}$ & 0,04 & $5,85^{*}$ \\
\hline Fatalistična motivacija & $4,87^{*}$ & 0,13 & 0,00 & 0,67 \\
\hline Narcistična motivacija & 0,11 & 0,03 & 1,72 & 0,00 \\
\hline Instrumentalna motivacija & 1,56 & $4,22^{*}$ & 0,03 & $4,07^{*}$ \\
\hline Instrumentalna motivacija 1 & 2,55 & 3,87 & 1,82 & $5,31^{*}$ \\
\hline Instrumentalna motivacija ${ }^{2}$ & 0,86 & 2,26 & 0,40 & 1,03 \\
\hline Instrumentalna motivacija ${ }^{3}$ & 0,65 & 2,49 & 0,03 & 1,74 \\
\hline Generativna briga & 1,29 & 0,01 & 0,00 & 0,03 \\
\hline
\end{tabular}

Napomene: Vrijednosti $\mathrm{u}$ tablici predstavljaju F-omjere; ${ }^{*} \mathrm{p}<0,05,{ }^{* *} \mathrm{p}<0,01,{ }^{* * *} \mathrm{p}<0,001$. 1,2,3 znače isto što i u Tablicama 1 i 2.

(1) TABLICA 3

Glavni i interakciiski efekti dvosmiernih ANCOVA (spol $\times$ dob: mlađi i sredovječni odrasli) za pojedine kategorije motivacije za roditelistvo i generativnu brigu, uz kontrolu broja diece kao kovarijate
Dobiveni rezultati pokazali su da je, uz kontrolu utjecaja broja djece, glavni efekt spola značajan za altruističnu i instrumentalnu motivaciju za roditeljstvo, dok je interakcija spola i dobi značajna za ove dvije kategorije motivacije za roditeljstvo, kao i za podvrstu instrumentalne motivacije koja se odnosi na očuvanje stabilnosti braka i sigurnost u starosti, što se navodilo kao razloge za roditeljstvo. Glavni efekt dobi nije se pokazao značajnim ni za jednu vrstu motivacije za roditeljstvo, kao ni za generativnu brigu.

U skladu s očekivanjima, žene $(M=42,98)$ imale su značajno izraženiju altruističnu motivaciju nego muškarci $(M=39,97)$. Analiza značajnoga interakcijskog efekta spola i dobi na altruističnu motivaciju primjenom Schefféova testa pokazala je postojanje značajnih razlika $(\mathrm{p}<0,01) \mathrm{u}$ izraženosti altruistične motivacije između podskupine muškaraca mlađe odrasle dobi $(\mathrm{M}=37,54)$ i svake od ostalih triju ispitanih podskupina, tj. žena mlađe odrasle dobi $(\mathrm{M}=42,42)$, sredovječnih muškaraca $(M=43,15)$ i sredovječnih žena $(M=42,82)$. $U$ sve tri usporedbe navedenih podskupina muškarci mlađe odrasle dobi izvijestili su o značajno slabijoj altruističnoj motivaciji za roditeljstvo.

Nadalje, rezultati su pokazali da je instrumentalna motivacija značajno izraženija u muškaraca $(M=46,74)$ nego u žena $(M=40,17)$. Dodatne analize utvrđenoga značajnog efekta interakcije spola i dobi na instrumentalnu motivaciju, upotrebom Schefféova testa, pokazale su značajnu razliku $(p<0,05)$ $\mathrm{u}$ instrumentalnoj motivaciji samo između podskupina sredovječnih muškaraca i sredovječnih žena. Pritom su sredovječni muškarci $(M=50,97)$ izvijestili o značajno izraženijoj instrumentalnoj motivaciji nego žene srednje dobi $(M=39,37)$. 
DRUŠ. ISTRAŽ. ZAGREB GOD. 21 (2012), BR. 2 (116)

STR. 363-382

TUCAK JUNAKOVIĆ, I., AHMETI, I.:

MOTIVACIJA ZA..
Dvosmjerne analize kovarijance na razini pojedinih podskala instrumentalne motivacije pokazuju samo značajan interakcijski efekt spola i dobi na rezultate na prvoj podskali instrumentalne motivacije koja se odnosi na očuvanje stabilnosti braka i sigurnost $\mathrm{u}$ starosti kao razloge za roditeljstvo. Pritom su značajne razlike $(\mathrm{p}<0,05)$ utvrđene između podskupine sredovječnih muškaraca i svake od ostale tri ispitane podskupine. U sredovječnih muškaraca $(M=16,92)$ ova je vrsta instrumentalnih motiva bila značajno zastupljenija negoli u mlađih muškaraca $(\mathrm{M}=12,53)$, mlađih žena $(\mathrm{M}=13,12) \mathrm{i}$ sredovječnih žena $(M=13,05)$.

Kako se iz Tablice 3 vidi, nakon kontrole utjecaja broja djece, $u$ fatalističnoj i narcističnoj fertilitetnoj motivaciji te $u$ generativnoj brizi nisu utvrđene značajne spolne i dobne razlike ni značajan interakcijski utjecaj spola i dobi na ove varijable.

Iz Tablice 3 se nadalje vidi da je broj djece sudionika istraživanja, kao kovarijata, imao značajan utjecaj jedino na samoprocjene altruistične i fatalistične motivacije za roditeljstvo. Veći broj djece bio je povezan s izraženijom altruističnom i fatalističnom motivacijom.

U nastavku su izračunani i koeficijenti parcijalne korelacije dobi s pojedinim kategorijama motivacije za roditeljstvo i s generativnom brigom, uz kontrolu utjecaja broja djece. Kao što analize kovarijance, uz kontrolu utjecaja broja djece, nisu potvrdile samostalan učinak dobi na ispitivane varijable, tako niti rezultati korelacijskih analiza, uz parcijalizaciju utjecaja broja djece, nisu potvrdili značajnu povezanost ni jedne kategorije motivacije za roditeljstvo, kao ni generativnosti, s dobi sudionika ovoga istraživanja.

\section{RASPRAVA}

Na prigodnom uzorku od 225 roditelja mlađe i srednje odrasle dobi provedeno je istraživanje čiji su ciljevi bili ispitati odnos generativne brige, tj. brige za mlađe naraštaje i za vlastite trajne doprinose društvu, i motivacije za roditeljstvo, te ispitati spolne $\mathrm{i}$ dobne razlike $\mathrm{u}$ toj motivaciji.

U skladu s istraživačkim hipotezama, pokazalo se da su altruistični i instrumentalni motivi za roditeljstvo uže povezani s generativnom brigom nego fatalistični i narcistični. Međutim, od tri skupine instrumentalnih motiva, generativna briga bila je značajno, iako nisko, povezana samo s instrumentalnim motivima koji se odnose na očuvanje stabilnosti braka i sigurnost u starosti, ali ne i s ostavljanjem traga za sobom i produženjem obiteljske loze kao motivima za roditeljstvo. Ne iznenađuje nalaz da fatalistična i narcistična motivacija, od kojih je prva relativno nesvjesna, a druga uglavnom sebična, nisu značajno povezane s generativnom brigom, kao svjesnom brigom za dobrobit pripadnika mlađih naraštaja. 
DRUŠ. ISTRAŽ. ZAGREB GOD. 21 (2012),

BR. $2(116)$

STR. 363-382

TUCAK JUNAKOVIĆ, I., AHMETI, I.:

MOTIVACIJA ZA...
Općenito se može zaključiti da generativna briga ipak nije u užoj vezi s motivacijom za roditeljstvo, jer su i one značajne korelacije s nekim vrstama te motivacije (altruističnom i instrumentalnom) niske. Mogući razlog ove slabe povezanosti jest taj što je koncept generativnosti mnogo širi od motivacije za roditeljstvo te je moguće da roditeljstvo u nekim slučajevima čak i ometa realizaciju nekih generativnih težnji, primjerice, $u$ slučaju onih pojedinaca koji uime šire brige za mlađe naraštaje i društvenu zajednicu zanemaruju vlastitu djecu.

Uz to, čini se da je broj djece utjecao na povezanost generativnosti i fertilitetne motivacije, jer je nakon kontrole njegova utjecaja korelacija generativnosti s altruističnom i instrumentalnom motivacijom bila još i niža. Zaista se i pokazalo da su neke vrste fertilitetne motivacije, tj. altruistična, fatalistična i ona vrsta instrumentalne koja se odnosi na očuvanje stabilnosti braka i sigurnost u starosti, značajno povezane s brojem djece. Te su korelacije bile niske do umjerene veličine. Ispitanici s većim brojem djece u retrospektivnom su osvrtu na svoje razloge za roditeljstvo izvijestili o izraženijim altruističnim, fatalističnim i spomenutim instrumentalnim motivima. Moguće je da su ih upravo ovi fertilitetni motivi i potaknuli na to da imaju veći broj djece ili je taj veći broj djece i uz njih vezana roditeljska iskustva utjecao na to da retrogradno izvješćuju o jačim altruističnim, fatalističnim i opisanim instrumentalnim motivima. Provedene analize kovarijance, uz broj djece kao kovarijatu, također su potvrdile značajan učinak broja djece na retrospektivne procjene altruistične $i$ fatalistične motivacije. No ipak treba istaknuti da je broj djece u ovom kontekstu varijabla koja ne pruža dovoljno informacija, jer je poznato da fertilitetna motivacija može biti različita za svako sljedeće dijete (Miller i Pasta, 1994.; Teachman i Schollaert, 1989.).

Rezultati ovoga istraživanja nadalje su pokazali da sve četiri ispitane kategorije motiva za roditeljstvo pozitivno i uglavnom umjereno visoko koreliraju. Očito $\mathrm{u}$ istih osoba fertilitetna motivacija može biti uvjetovana višestrukim i vrlo različitim razlozima, koji se razlikuju po svojoj snazi, osviještenosti, "sebičnosti" i drugim obilježjima. No, kao što se i moglo očekivati, u najvećoj su korelaciji bile instrumentalna i narcistična motivacija, jer u objema dijete služi postizanju nekoga roditeljskog cilja, bilo da je riječ o produženju obiteljskog imena, osiguranju u starosti ili dokazivanju vlastite vrijednosti. Nesebična altruistična motivacija, izražena u želji da se ima dijete zbog ljubavi, veselja koje pruža i želje da se o njemu brine, izdvaja se od ostalih kategorija motivacije za roditeljstvo. Stoga i ne iznenađuje što je najslabije bila povezana s narcističnom motivacijom te što su općenito njezine povezanosti s instrumentalnom, fatalističnom i narcističnom motivacijom bile niže nego međusobne povezanosti tih triju kategorija motivacije za roditeljstvo. 
DRUŠ. ISTRAŽ. ZAGREB GOD. 21 (2012), BR. $2(116)$

STR. 363-382

TUCAK JUNAKOVIĆ, I., AHMETI, I.:

MOTIVACIJA ZA...
Kada se analizira zastupljenost pojedinih kategorija motiva, može se reći da je u ispitanom uzorku odraslih najizraženija bila altruistična motivacija, zatim fatalistična, instrumentalna, a najmanje izražena narcistična motivacija. Među instrumentalnim motivima najzastupljeniji su bili oni koji se odnose na očuvanje stabilnosti braka i osiguranje sigurne starosti uz pomoć djece, na drugom mjestu oni koji se odnose na produženje obiteljske loze i ostavljanje traga za sobom, a najmanje zastupljeni bili su oni koji se odnose na postizanje višega društvenog statusa i domoljubne motive za roditeljstvo. Vjerojatno pronatalitetna politika, posebno izražena neposredno nakon Domovinskog rata, u današnje vrijeme više toliko ne utječe na fertilitetnu motivaciju pojedinaca. Ohrabrujući je nalaz da su sudionici ovoga istraživanja kao glavne razloge za roditeljstvo prepoznali ljubav prema djeci, želju da se o njima brinu, da ih štite i sl., dok su fatalistični te "sebičniji" narcistični i instrumentalni motivi, poput nastavljanja loze putem djece, ispunjavanja domoljubne dužnosti, dokaza muškosti/ženstvenosti itd., bili manje prepoznati kao vlastiti. Sudionici ovoga istraživanja bile su odrasle osobe, a altruistični motivi i trebali bi se pojačavati s dobi, kao odraz sazrijevanja i rastuće spremnosti pojedinca da pruži zaštitu, žrtvuje se i brine o pripadnicima mlađih naraštaja. Slično ovome, Kapor-Stanulović (1984.) također je utvrdila da su u odraslih muškaraca i žena najzastupljeniji altruistični motivi, a nakon njih fatalistični. Međutim, isto je utvrdila i za uzorke adolescenata i studenata.

$\mathrm{U}$ pogledu spolnih razlika u motivaciji za roditeljstvo, $\mathrm{u}$ skladu s očekivanjima, pokazalo se da žene imaju izraženiju altruističnu motivaciju, dok je instrumentalna motivacija bila značajno izraženija u muškaraca. U skladu s razlikama u procesu socijalizacije rodnih uloga, u kojem je kod žena veći naglasak na empatiji, brizi za druge i osjetljivosti za tuđe potrebe, i moglo se očekivati da će one, u odnosu na muškarce, imati izraženije altruistične motive ljubavi, brige i zaštite djece kao razloge za roditeljstvo. Ovaj je rezultat u skladu s nalazom Lacković-Grgin i Vitez (1997.) da je femininost značajan prediktor altruistične motivacije za roditeljstvo te u skladu s nalazom Kapor-Stanulović (1984.) da je u djevojaka izraženija altruistična motivacija nego u mladića. S druge strane, instrumentalni motivi, kao što su, primjerice, produženje loze, postizanje većega društvenog statusa ili ostavljanje traga za sobom, vjerojatno su više u skladu s muškom rodnom ulogom, koja uključuje instrumentalne osobine poput poduzetnosti, produktivnosti, asertivnosti, dominantnosti i sl. Očito se muškarci više nego žene koriste roditeljstvom u svrhu postizanja konkretnih ciljeva. Uz to, muškarcima je kao nositeljima obiteljskoga prezimena možda važnije nego ženama nastaviti o- 
DRUŠ. ISTRAŽ. ZAGREB GOD. 21 (2012)

BR. $2(116)$

STR. 363-382

TUCAK JUNAKOVIĆ, I., AHMETI, I.

MOTIVACIJA ZA... biteljsku lozu. Međutim, nalaz o izraženijoj instrumentalnoj motivaciji u muškaraca ne poklapa se s rezultatima nekih drugih istraživanja, koja su pokazala da je instrumentalna motivacija za roditeljstvo izraženija u žena i da je povezana s osobinom femininosti, što je objašnjeno time da se mnoge žene poistovjećuju sa stereotipom o ženama kao slabijem spolu kojem je potrebna zaštita koju mogu osigurati vlastita djeca (Lacković-Grgin i Vitez, 1997.). Ima i istraživanja koja pokazuju da $\mathrm{u}$ instrumentalnoj motivaciji nema značajnih spolnih razlika (Kapor-Stanulović, 1984.).

Dob nije imala samostalan značajan učinak na fertilitetnu motivaciju nakon kontrole broja djece. Razlike između mlađih i sredovječnih odraslih nisu utvrđene, možda zato što su i jedni i drugi, bez obzira na razlike u svojoj kronološkoj dobi $\mathrm{u}$ vrijeme ispitivanja fertilitetne motivacije, svoju fertilitetnu odluku većinom donijeli vjerojatno $u$ istom razdoblju, tj. u mlađoj odrasloj dobi. Dakle, vjerojatno je slična dob u kojoj su donijeli fertilitetnu odluku utjecala na sličnu zastupljenost na ovaj način ispitanih fertilitetnih motiva u osoba mlađe i srednje odrasle dobi. $S$ druge strane, razlike $u$ dobi ispitanika $u$ trenutku ispitivanja, odnosno razlike u vremenu koje je proteklo između trenutka donošenja fertilitetne odluke i trenutka ispitivanja fertilitetne motivacije, očito se nisu značajnije odrazile na ovako procijenjenu fertilitetnu motivaciju roditelja mlađe i srednje odrasle dobi. U ovom je istraživanju kronološka dob ispitanika vjerojatno usko povezana s vremenom između trenutka donošenja fertilitetne odluke i trenutka ispitivanja fertilitetne motivacije. Pritom su stariji ispitanici fertilitetnu odluku vjerojatno donijeli, u odnosu na vrijeme ispitivanja, mnogo prije mlađih, osim u slučaju osoba koje su kasno postale roditeljima. Međutim, o tome ne možemo pouzdano govoriti jer nemamo podatak o roditeljskom stažu ispitanika, odnosno o dobi njihove djece.

Uzimajući stoga u obzir oprez prilikom objašnjenja značenja utjecaja dobi ispitanika u ovom kontekstu, nadalje se pokazalo da je dob u interakciji sa spolom ispitanika ipak imala značajan učinak na altruističnu, instrumentalnu motivaciju općenito i onu vrstu instrumentalne motivacije koja se odnosi na osiguranje sigurne starosti i stabilnoga braka uz pomoć djece. Muškarci mlađe odrasle dobi, u odnosu na sredovječne muškarce te žene mlađe i srednje odrasle dobi, izvijestili su o najslabijoj altruističnoj motivaciji za roditeljstvo. Vjerojatno su mlađi muškarci više zaokupljeni profesionalnim ambicijama, postizanjem određenoga statusa u zanimanju te usmjereni na instrumentalne osobine kao što su nezavisnost, dostignuća, poduzetnost i sl. Značajan interakcijski utjecaj spola i dobi na instrumentalnu motivaciju općenito i prvu podskalu instrumentalne motivacije pokazao je da muškarci srednje 
DRUŠ. ISTRAŽ. ZAGREB GOD. 21 (2012), BR. 2 (116)

STR. 363-382

TUCAK JUNAKOVIĆ, I., AHMETI, I.: MOTIVACIJA ZA... dobi izvješćuju o značajno izraženijoj ukupnoj instrumentalnoj motivaciji u odnosu na žene srednje dobi te da je $u$ muškaraca srednje dobi značajno zastupljenija ona vrsta instrumentalnih motiva koji se odnose na očuvanje stabilnosti braka i sigurnost u starosti, što su navodili kao razloge za roditeljstvo, nego u mlađih muškaraca te mlađih i sredovječnih žena. Vjerojatno su procjene fertilitetne motivacije u sredovječnih muškaraca ipak dijelom bile pod utjecajem njihove trenutačne razvojne pozicije sredovječnih osoba koje se pribojavaju starosti koja se približava, pa se možda nadaju da će zahvaljujući djeci starost učiniti sigurnijom, učvrstiti brak, osigurati nastavak obiteljske loze i sl.

Na kraju treba spomenuti i glavna ograničenja provedenog istraživanja i smjernice za buduća slična istraživanja. Uz ograničenja koja se odnose na nereprezentativan uzorak i sumnju u socijalno poželjno odgovaranje, vjerojatno je glavno ograničenje ovoga istraživanja to što je provedeno kao retrospektivno. Dakle, nisu ispitivani njihovi trenutačni razlozi zbog kojih bi željeli imati dijete/djecu u budućnosti, nego su ispitanici procjenjivali motive zbog kojih su se odlučili imati dijete/djecu koju već imaju. Može se pretpostaviti da je njihovo sjećanje na te motive iskrivljeno činjenicom da već jesu roditelji i da vole svoju djecu, što je moglo utjecati na češće iskazivanje nekih motiva, primjerice altruističnih. Međutim, $u$ istraživanju trenutačne motivacije za roditeljstvo koje se tek planira vjerojatno ne bi mogle sudjelovati sredovječne osobe koje su već ostvarile planove da postanu roditeljima ili, ako nisu, vjerojatno su od njih odustale.

S obzirom na navedena ograničenja provedenoga istraživanja, dobivene bi rezultate trebalo tretirati prije svega kao smjernicu za buduća istraživanja složenijega nacrta u kojima bi valjalo provjeriti ostaje li veza generativnosti i motivacije za roditeljstvo uistinu slaba i kada tu motivaciju procjenjuju one osobe koje tek namjeravaju imati djecu. Kako je pretpostavljeno da bi generativnost mogla biti jedan od izvora fertilitetne motivacije, da se budućim rigoroznijim istraživanjima utvrdi značajna i veća povezanost generativnosti i nekih vrsta ove motivacije (npr. altruistične), na osnovi toga moglo bi se sugerirati da bi poticanje generativne brige moglo ojačati te vrste fertilitetne motivacije. Međutim, kada je riječ o korelacijskim nacrtima, ne bi se moglo isključiti niti alternativno tumačenje da bi želja za roditeljstvom, ili stvarno preuzimanje roditeljske uloge, moglo potaknuti razvoj generativnosti.

U buduća bi istraživanja motivacije za roditeljstvo i njezina odnosa s generativnosti, uz obrazovanje i broj djece, valjalo uključiti i druge relevantne varijable, kao što su financije, zaposlenje, stavovi, vrijednosti i osobine ličnosti potencijalnih roditelja, spol i redoslijed rođenja djece za one koji su već roditelji itd. 
Adler, M. A. (1997.), Social Change and Declines in Marriage and Fertility in Eastern Germany. Journal of Marriage and the Family, 59 (1): 37-49. doi: $10.2307 / 353660$

Bradley, C. L. (1997.), Generativity-Stagnation: Development of a Status Model. Developmental Review, 17 (3): 262-290. doi:10.1006/drev. 1997.0432

Čudina-Obradović, M. i Obradović, J. (2006.), Rađanje djece u obitelji. U: Psihologija braka i obitelji (str. 199-239), Zagreb, Golden marketing-Tehnička knjiga.

Erikson, E. (1984.), Childhood and Society, London, Triad Paladin.

Friedman, D., Hechter, M. i Kanazawa, S. (1994.), A Theory of the Value of Children. Demography, 31: 375-401. doi:10.2307/2061749

Helgeson, V. S. (1994.), Relation of Agency and Communion to Well-Being: Evidence and Potential Explanations. Psychological Bulletin, 116: (3) 412-428. doi:10.1037/0033-2909.116.3.412

Hoffman, L. W. i Hoffman, M. (1973.), The Value of Children to Parents. U: J. T. Fawcett (ur.), Psychological Perspectives on Population (str. 19-77), New York, Basic Books.

Kapor-Stanulović, N. (1984.), Motivacija za roditeljstvom: razlike po polu i uzrastu. Psihologija, 1-2: 42-48.

Kapor-Stanulović, N. (1985.), Psihologija roditeljstva, Beograd, Nolit.

Kohler, H., Rodgers, J. L. i Christensen, K. (1999.). Is Fertility Behavior in Our Genes? Findings from a Danish Twin Study. Population and Development Review, 25 (2): 253-288. doi:10.1111/j.1728-4457.1999.00253.x

Kotre, J. (1984.), Outliving the Self: Generativity and the Interpretation of Lives, Baltimore, John Hopkins University Press.

Lacković-Grgin, K., Penezić, Z. i Tucak, I. (2002.), Odnos generativnosti i drugih komponenti ličnosti Eriksonova modela u osoba mlađe, srednje i starije odrasle dobi. Suvremena psihologija, 5 (1): 9-30.

Lacković-Grgin, K. i Vitez, S. (1997.), Predikcija Rabinovih kategorija motivacije za roditeljstvo. Radovi Filozofskog fakulteta u Zadru, Razdio FPSP, 36 (13): 43-62.

Lacković-Grgin, K. i Vitez, S. (2002.), Skala motivacije za roditeljstvo (MZR). U: K. Lacković-Grgin, A. Proroković, V. Ćubela i Z. Penezić (ur.), Zbirka psihologijskih skala $i$ upitnika, svezak 1 (str. 63-66), Zadar, Filozofski fakultet u Zadru.

McAdams, D. P. (1993.), The Stories We Live By: Personal Myths and the Making of the Self, New York, The Guilford Press.

McAdams, D. P. i de St. Aubin, E. (1992.), A Theory of Generativity and Its Assessment through Self-Report, Behavioral Acts and Narrative Themes in Autobiography. Journal of Personality and Social Psychology, 62 (6): 1003-1015. doi:10.1037/0022-3514.62.6.1003

McAdams, D. P., Hoffman, G. J., Mansfield, E. D. i Day, R. (1996.), Themes of Agency and Communion in Significant Autobiographical Scenes. Journal of Personality, 64 (2): 339-377. doi:10.1111/j.1467-6494. 1996.tb00514.x 
DRUŠ. ISTRAŽ. ZAGREB GOD. 21 (2012), BR. 2 (116)

STR. 363-382

TUCAK JUNAKOVIĆ, I., AHMETI, I.: MOTIVACIJA ZA..
Miller, W. B. i Pasta, D. J. (1994.), The Psychology of Child Timing: A Measurement Instrument and a Model. Journal of Applied Social Psychology, 24 (3): 218-250. doi:10.1111/j.1559-1816.1994.tb00580.x

Peterson, B. E. (2006.), Generativity and Successful Parenting: An Analysis of Young Adult Outcomes. Journal of Personality, 74 (3): 847-870. doi:10.1111/j.1467-6494.2006.00394.x

Peterson, B. E. i Klohnen, E. C. (1995.), Realization of Generativity in Two Samples of Women at Midlife. Psychology and Aging, 10 (1): 20-29. doi:10.1037/0882-7974.10.1.20

Peterson, B. E., Smirles, K. A. i Wentworth, P. A. (1997.), Generativity and Authoritarianism: Implications for Personality, Political Involvement, and Parenting. Journal of Personality and Social Psychology, 72 (5): 1202-1216. doi:10.1037/0022-3514.72.5.1202

Peterson, B. E. i Stewart, A. J. (1993.), Generativity and Social Motives in Young Adults. Journal of Personality and Social Psychology, 65 (1): 186-198. doi:10.1037/0022-3514.65.1.186

Pratt, M. W., Danso, H. A., Arnold, M. L., Norris, J. E. i Filyer, R. (2001.), Adult Generativity and the Socialization of Adolescents: Relations to Mothers' and Fathers' Parenting Beliefs, Styles, and Practices. Journal of Personality, 69 (1): 89-120. http://dx.doi.org/10.1111/ 1467-6494.00137

Rabin, A. I. (1965.), Motivation for Parenthood. Journal of Projective Techniques and Personality Assessment, 29 (4): 405-413. doi:10.1080/00 91651X.1965.10120230

Schoen, R., Kim, Y. J., Nathanson, C. A., Fields, J. i Astone, N. M. (1997.), Why Do Americans Want Children? Population and Development Review, 23 (2): 333-358. doi:10.2307/2137548

Snarey, J. i Clark, P. Y. (1998.), A Generative Drama: Scenes from a Father-Son Relationship. U: D. P. McAdams i E. de St. Aubin (ur.), Generativity and Adult Development: How and Why We Care for the Next Generation (str. 45-74), Washington, D.C., APPA Press.

Stewart, A. J., Franz, E. i Layton, L. (1988.), The Changing Self: Using Personal Documents to Study Lives. Journal of Personality, 56 (1): 41-74. doi:10.1111/j.1467-6494.1988.tb00462.x

Stewart, A. J. i Vandewater, E. A. (1998.), The Course of Generativity. U: D. P. McAdams i E. de St. Aubin (ur.), Generativity and Adult Development: How and Why We Care for the Next Generation (str. 75-100), Washington, D.C., APPA Press.

Teachman, J. D. i Schollaert, P. T. (1989.), Gender of Children and Birth Timing. Demography, 26 (3): 411-423. doi:10.2307/2061601

Tucak, I. (2005.), Generativna briga u tri perioda odrasle dobi: relacija s nekim sociodemografskim varijablama, životnim zadovoljstvom i percepcijom osobne (ne)kompetentnosti. Suvremena psihologija, 8 (2): 179-195. 
DRUŠ. ISTRAŽ. ZAGREB GOD. 21 (2012)

BR. 2 (116),

STR. 363-382

TUCAK JUNAKOVIĆ, I., AHMETI, I.

MOTIVACIJA ZA...

\section{Motivation for Parenthood and Concern for the Next Generation in Younger and Middle Aged Parents}

Ivana TUCAK JUNAKOVIĆ, Iva AHMETI

University of Zadar, Zadar

The study was conducted with the first aim to examine the relation of the four categories of motivation for parenthood, toward Rabin (Rabin, 1965), with generative concern or the concern for the welfare of the next generation. Parenthood is the most common, although not the only way of expressing generativity, for which it was assumed to be one of the sources of motivation for parenthood. The other aim was to test gender and age differences in motivation for parenthood. 225 parents, 20 to 60 years old, participated in the study. Their reasons for heaving child/children were assessed using the Motivation for Parenthood Scale, while generative concern was measured by the adapted Loyola Generativity Scale. The results have shown that generative concern correlates significantly, but lowly, with altruistic and instrumental motivation for parenthood, while correlations of generative concern with fatalistic and narcissistic motives were not significant. Women have higher altruistic motivation than men, while men had higher instrumental motivation than women. While controlling for number of children, younger and middle aged parents did not differ significantly in their assessment of the categories of motivation for parenthood. However, in interaction with gender, subjects' age had significant effect on altruistic and instrumental motivation.

Keywords: motivation for parenthood, generative concern, gender and age differences 